\title{
Analisis Bauran Promosi yang Paling Berpengaruh Terhadap Keputusan Mahasiswa dalam Memilih Universitas Sarjanawiyata Tamansiswa
}

\author{
Imas Nursiwan Dono', Susanto², Bernadetta Diansepti Maharani ${ }^{3}$ \\ Universitas Sarjanawiyata Tamansiswa \\ imasbta9@gmail.com
}

\begin{abstract}
The purpose of this study was to analyze the Influence of Promotion Mix which Most Influences on Student Decisions in Choosing Sarjanawiyata Tamansiswa University. The research methodology used is descriptive quantitative method, the unit of analysis in this study is Sarjanawiyata Tamansiswa University and the observation unit is the students of the Sarjanawiyata Tamansiswa University. The population in this study were 4,270 respondents from Sarjanawiyata Tamansiswa University. The technique for determining the number of samples used in this study is the Slovin formula and totals 135 respondents. The research method used is data collection techniques through questionnaires which are carried out systematically in accordance with the research objectives. The analysis method used to solve problems and prove the hypothesis is descriptive analysis and regression analysis. This analysis includes validity and reliability tests, classic assumption tests, multiple linear regression analysis, hypothesis testing through the F test and $t$ test, the coefficient of determination (R2) and thetest Standardized Beta Coefficient. The results of the F test show that simultaneously Advertising, Personal Selling, Sales Promotion and Publicity have a positive and significant effect on student decisions in choosing Sarjanawiyata Tamansiswa University. The results of the $t$ test partially show that the Advertising variable and the Sales Promotion variable have a positive and significant effect on student decisions in choosing Sarjanawiyata Tamansiswa University, the Personal Selling variable and the Publicity variable have no positive or significant effect on student decisions in choosing Sarjanawiyata Tamansiswa University. The results of the coefficient of determination (R2) test show that student decisions are influenced by the variables of Advertising, Personal Selling, Sales Promotion, and Publicity, while the rest is explained by other variables not discussed in this study. Judging from the results of Standarized Beta Coefficient, it shows that the most dominant variable in this study and the most influential on student decisions is advertising.
\end{abstract}

Keywords: Advertising, Personal Selling, Sales Promotion, dan Publicity.

\begin{abstract}
ABSTRAK
Tujuan penelitian ini adalah menganalisa Pengaruh Bauran Promosi (Advertising, Personal Selling, Sales Promotion, dan Publicity) Yang Paling Berpengaruh Terhadap Keputusan Mahasiswa Dalam Memilih Universitas Sarjanawiyata Tamansiswa. Metodologi penelitian yang digunakan adalah metode deskriptif kuantitatif, unit analisis dalam penelitian ini adalah Universitas Sarjanawiyata Tamansiswa dan unit observasi adalah mahasiswa Universitas Sarjanawiyata Tamansiswa tahun angkatan 2019/2020 dan angkatan 2020/2021. Populasi dalam penelitian ini adalah 4.270 responden dari tahun angkatan 2019/2020 dan angkatan 2020/2021 Universitas Sarjanawiyata Tamansiswa. Teknik penentuan jumlah sampel yang digunakan dalam penelitian ini adalah rumus Slovin dan berjumlah 135 responden. Metode penelitian yang digunakan adalah teknik
\end{abstract}


pengumpulan data melalui penyebaran kuesioner yang dilakukan secara sistematis sesuai dengan tujuan penelitian. Metode analisis yang digunakan untuk memecahkan masalah dan membuktikan hipotesis adalah analisis deskriptif dan analisis regresi. Analisis ini meliputi uji validitas dan reliabilitas, uji asumsi klasik, analisis regresi linier berganda, uji hipotesis melalui uji $\mathrm{F}$ dan uji t, uji koefisien determinasi (R2) dan uji Standarized Beta Coeficient. Hasil uji F menunjukkan bahwa Advertising, Personal Selling, Sales Promotion, dan Publicity secara simultan berpengaruh positif dan signifikan terhadap keputusan mahasiswa dalam memilih Universitas Sarjanawiyata Tamansiswa. Hasil uji t menunjukkan bahwa variabel Advertising berpengaruh positif dan signifikan terhadap keputusan mahasiswa dalam memilih Universitas Sarjanawiyata Tamansiswa, variabel Personal Selling tidak berpengaruh positif atau signifikan terhadap keputusan mahasiswa dalam memilih Universitas Sarjanawiyata Tamansiswa, variabel Publicity tidak berpengaruh positif dan signifikan terhadap keputusan mahasiswa dalam memilih Universitas Sarjanawiyata Tamansiswa, dan variabel Sales Promotion berpengaruh positif dan signifikan terhadap keputusan mahasiswa dalam memilih Universitas Sarjanawiyata Tamansiswa. Hasil uji koefisien determinasi (R2) menunjukkan bahwa Keputusan mahasiswa dipengaruhi oleh variabel Advertising, Personal Selling, Sales Promotion, dan Publicity, sedangkan sisanya dijelaskan oleh variabel lain yang tidak dibahas dalam penelitian ini. Dilihat dari hasil Standarized Beta Coeficient menunjukkan variabel paling dominan dalam penelitian ini dan paling berpengaruh terhadap Keputusan Mahasiswa adalah Advertising.

Keywords: Advertising, Personal Selling, Sales Promotion, dan Publicity.

\section{PENDAHULUAN}

Semakin berkembangnya zaman di dunia, pendidikan adalah salah satu prioritas bagi kebanyakan orang. Hal ini dikarenakan pendidikan merupakan aset penting untuk jaminan masa depan setiap orang (individu), dengan pendidikan seseorang akan mendapatkan bekal yang dapat meningkatkan kualitas pola pikir (cara berfikir), membentuk kepribadian yang jauh lebih baik seseorang menurut ukuran normatif, dan meningkatkan kesadaran masyarakat tentang maanfaat pendidikan untuk masa depan setiap orang (Astuti, 2015). Sehingga saat ini banyak orang tua yang ingin memberikan pendidikan tertinggi dan terbaik buat anak-anak mereka.

Sejalan dengan hal tersebut, melihat semakin banyak para orang tua yang ingin memberikan pendidikan terbaik buat anak-anaknya, pendidikan di indonesia saat ini berkembang dengan pesat. Baik mulai dari pendidikan SD, SMP, SMA dan terutama perguruan tinggi. Saat ini banyak perguruan tinggi baik yang swasta maupun negeri saling bersaing (berlomba-lomba) untuk meningkatkan kualitas pendidikan di setiap Universitas, agar jumlah mahasiswa yang mendaftar kuliah di Universitas semakin meningkat. Dimana mana masing- masing perguruan tinggi saling bersaing dalam hal promosi.

Menurut Lupiyoadi (2013) dalam (Astuti, 2015) menyatakan bahwa Kegiatan promosi bukan hanya berfungsi sebagai alat komunikasi perusahaan dengan konsumen, melainkan juga berguna untuk membantu perusahaan dalam mempengaruhi konsumen dalam aktivitas pembelian atau pemakaian jasa sesuai dengan kemauan dan kebutuhan yang diperlukan konsumen. Menurut Novita Klarisa (2013) Promosi adalah segala jenis kegiatan perusahaan untuk mengkomunikasikan produknya pada pasar yang menjadi sasarannya. Menurut Zainurin Dahari, (2011) Promosi merupakan hal penting dalam setiap aspek bisnis. Hal ini 
dikarenakan promosi mencakup semua alat yang digunakan perusahaan untuk menyediakan pasar dengan informasi tentangnya penawaran, periklanan, publisitas, hubungan masyarakat dan penjualan upaya promosi. Dari berbagai pendapat dan pengertian para ahli di atas mengenai promosi, maka dapat di simpulkan bahwa promosi adalah suatu usaha yang dilakukan oleh perusahaan yang bertujuan menarik perhatian dan mempengaruhi konsumen untuk membeli produk. Tujuan Promosi adalah menyebarkan informasi produk kepada setiap target pasar yang memiliki potensial, yang berguna untuk mendapatkan kenaikan penjualan dan profit, untuk mendapatkan konsumen baru dan menjaga kesetiaan konsumen, untuk menjaga kestabilan penjualan ketika pasar sedang lesu, membedakan serta mengunggulkan produk kita dengan produk pesaing, dan membentuk citra produk di mata konsumen sesuai dengan yang diinginkan (Setiono, 2010). Seperti halnya dalam menghadapi persaingan diperguruan tinggi, diperlukan pemilihan strategi pemasaran yang tepat termasuk dalam penggunaan strategi promosi (Mulyawan \& Komarudin. 2012), karena dengan menggunakan strategi yang tepat dalam promosi Universitas, ini akan sangat berpengaruh terhadap penambahan jumlah mahasiswa yang masuk dalam Universitas setiap tahunnya.

Sebagai salah satu perguruan tinggi swasta di Daerah Istimewa Yogyakarata, Universitas Sarjanawiyata Tamansiswa (UST) tidak dapat mempungkiri bahwa akan dihadapkan dengan banyak persaingan dari universitas lain dalam meningkatkan tiap jumlah mahasiswa setiap tahunnya. Tercatat Daerah Istimewa Yogyakarta (DIY) tiap tahunya mengalami peningkatan jumlah mahasiswa yang ingn melanjutkan pendidikan ke perguruan tinggi. Menurut Badan Pusat Statistika (BPS) tahun 2020 tercatat 368.066 mahasiswa yang melanjutkan dan menempuh pendidikan di perguruan tinggi di daerah DIY. Diantara jumlah tersebut sekitar 268.243 mahasiswa memilih kampus swasta, yang terbagi-bagi pada 106 Universitas Swasta yang ada di DIY yang salah satunya di UST. Hal ini nantinya akan berpengaruh terhadap peningkatan minat mahasiswa dalam memilih Universitas yang ada di DIY, terutama di Universitas Sarjanawiyata Tamansiswa (UST). Terhitung penambahan jumlah mahasiswa di 2 tahun untuk angkatan 2019/2020 \& 2020/2021 dapat dilihat pada diagram 1.1 berikut :

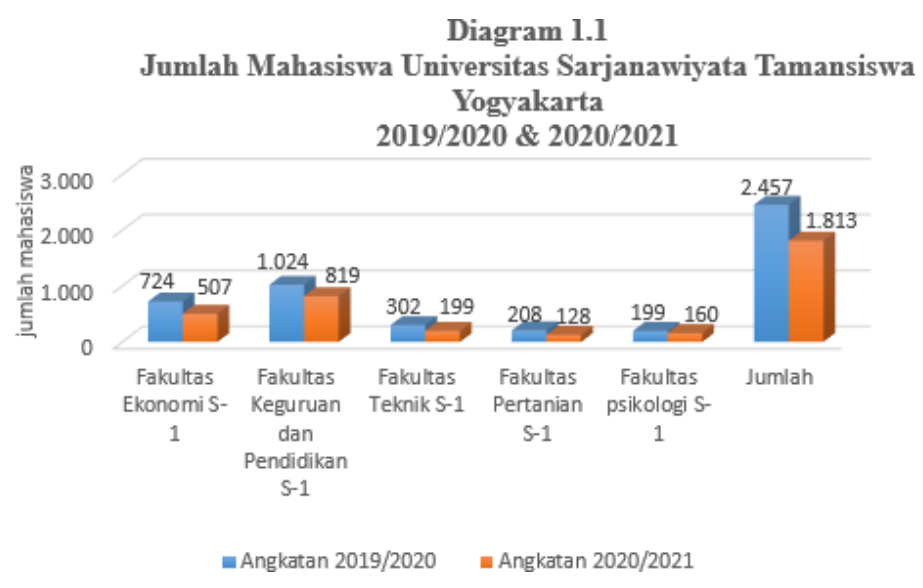

Diagram 1.1 menunjukan penambahan jumlah mahasiswa di dua tahun terakhir, yang mana terjadi penurunan jumlah mahasiswa yang cukup segnifikan pada Universitas Sarjanawiyata Tamansiswa. Dimana pada angkatan tahun 2019/2020 jumlah mahasiswa sebesar 2.457 sedangkan pada angkatan tahun 2020/2021 jumlah mahasiswa menurun 
menjadi 1.813. Penurunan jumlah mahasiswa baru yang memilih UST, ini dipengaruhi oleh banyak faktor yang salah satunya dipengaruhi oleh bauran promosi yang dilakukan oleh Universitas Sarjanawiyata Tamansiswa. Menurut George E. Belch \& Michael A. Michael Belch (2004) dalam (Imasari \& Lu, 2010) Bauran Promisi adalah pengorganisasian dari semua kegiatan penjualan yang dilakukan perusahaan untuk menyediakan informasi yang bertujuan untuk memasarkan barang atau jasa dan mempromosikan gagasan perusahaan. Sedangkan Menurut Siti Salbiyah (2018) bauran promosi merupakan alat yang paling efektif untuk berkomunikasi antara perusahaan dengan pelanggan (baik konsumen maupun perantara), yang nantinya akan berkaitan dengan upaya perusahaan untuk mengendalikan konsumen agar dapat mengenali produk perusahaan lalu memahaminya, berubah sikap, menyukai, yakin kemudian akhirnya memutuskan untuk membeli dan selalu ingat akan produk tersebut. Penggunaan bauran promosi yang dilakukan setiap perusahaan merupakan salah satu strategi untuk membangun komunikasi yang dilakukan oleh perusahaan dengan tujuan meningkatkan nilai dan membangun hubungan yang baik dengan konsumen (Jasmani \& Sunarsi, 2020). Maka dari pendapatan masing-masing para ahli mengenai bauran peomosi dapat ditarik kesimpulan bahwa bauran promosi adalah alat yang terdiri dari Variabel Advertising, Personal Selling, Publicity, dan Sales Promotion yang digunakan perusahaan untuk mencapai tujuanpemasaran perusahaan.

Bauran promosi adalah gabungan strategi yang paling tepat antara Variabel Advertising, Personal Selling, Publicity, dan Sales Promotion yang diatur dengan tujuan mencapai program penjualan perusahaan (Abdi \& Hariyadi, 2017). Advertising, yaitu bentuk presentasi dan promosi bukan pribadi tentang ide, produk dan jasa yang dibayar oleh sponsor tertentu. Dalam pemasaran jasa pendidikan, "Periklanan yaitu bentuk-bentuk komunikasi yang meliputi siaran radio (broadcast), materi tercetak (print), internet, papan reklame (Outdoor Advertising) dan surat langsung (direct mail) yang dilakukan pemasar jasa pendidikan", Personal Selling yaitu penyampaian secara lisan mengenai produk dalam bentuk percakapan dengan satu atau lebih calon pembeli yang diarahkan untuk menciptakan penjualan. Dalam pemasaran jasa pendidikan, penjualan pribadi bisa disebut dengan komunikasi pribadi, dalam artian "komunikasi yang secara langsung antara pemasar jasa pendidikan dan konsumen jasa pendidikan yang melibatkan percakapan dua arah dalam menyapaikan penjualan produk jasa pendidikan, seperti percakapan tatap muka, panggilan telepon dan surat elektronik", Publicity, yaitu upaya yang dilakukan perusahaan untuk menciptakan permintaan bukan secara pribadi pada produk, jasa, atau ide dengan menggunakan berita komersial di media massa dan sponsor yang tidak dibebankan sejumlah pembayaran secara langsung. Adapun dalam jasa pendidikan untuk memicu minat yang efektif terhadap sekolah dan produk jasa pendidikan lainya dapat melalui penyebaran berita baru, membuat konverensi pers, menyelenggarakan peristiwa istimewa dan mendanai (memberikan modal) kegiatan yang pantas dijadikan sebuah berita oleh pihak ketiga sekolah", Sales Promotion, yaitu kegiatan penjualan selain penjualan pribadi, periklanan dan publisitas yang memberikan dukungan terhadap pembelian konsumen dan efektivitas peritel dalam bentuk peragaan, pertunjukan, pameran, demonstrasi dan sebagainya. Dalam pemasaran jasa pendidikan "Promosi penjualan yaitu bentuk motivasi jangka pendek yang ditawarkan kepada pelanggan jasa pendidikan maupun perantara jasa pendidikan untuk memicu pembelian produk jasa pendidikan, sales 
promotion dalam jasa pendidikan dapat berupa kupon (coupon) produk jasa pendidikan, diskon (discout) produk jasa pendidikan, hadiah (gift) dan promosi berhadiah (prize promotion)" (Wijaya 2012: 165) dalam (Siti Salbiyah, 2018).

Tujuan dari penelitian ini adalah untuk menganalisis pengaruh bauran promosi yang terdiri dari Advertising, Personal Selling, Sales Promotion, dan Publicity yang paling berpengaruh terhadap keputusan mahasiswa baru dalam memilih Universitas Sarjanawiyata Tamansiswa.

Penelitian terdahulu yang dilakukan oleh (Mulyawan \& Komarudin., 2012) membuktikan bahwa Advertising paling berpengaruh positif terhadap keputusan mahasiswa dalam memilih universitas STMIK Mardira Indonesia, Bandung. Penelitian lainnya dilakukan oleh (Abdi \& Hariyadi, 2017) juga membuktikan bahwa Advertising paling berpengaruh positif terhadap keputusan mahasiswa dalam memilih Universitas Muhammadiyah Sumatra Barat, (Setyowati \& Aesthetika, 2018) juga membuktikan bahwa Advertising paling berpengaruh positif terhadap keputusan mahasiswa dalam memilih Universitas Muhammadiyah Sidoarjo (UMSIDA).

\section{KAJIAN LITERATUR}

\subsection{Bauran Promosi}

Menurut Abdi \& Hariyadi (2017) bauran promosi adalah gabungan strategi yang paling tepat antara Variabel Advertising, Personal Selling, Publicity, dan Sales Promotion yang diatur dengan tujuan mencapai program penjualan perusahaan.

Menurut Siti Salbiyah (2018) bauran promosi merupakan alat yang paling efektif untuk berkomunikasi antara perusahaan dengan pelanggan (baik konsumen maupun perantara), yang nantinya akan berkaitan dengan upaya perusahaan untuk mengendalikan konsumen agar dapat mengenali produk perusahaan lalu memahaminya, berubah sikap, menyukai, yakin kemudian akhirnya memutuskan untuk membeli dan selalu ingat akan produk tersebut. Penggunaan bauran promosi yang dilakukan setiap perusahaan merupakan salah satu strategi untuk membangun komunikasi yang dilakukan oleh perusahaan dengan tujuan meningkatkan nilai dan membangun hubungan yang baik dengan konsumen (Jasmani \& Sunarsi, 2020).

Maka dari pendapatan masing-masing para ahli mengenai bauran peomosi dapat ditarik kesimpulan bahwa bauran promosi adalah alat yang terdiri dari Variabel Advertising, Personal Selling, Publicity, dan Sales Promotion yang digunakan perusahaan untuk mencapai tujuan pemasaran perusahaan.

Menurut Wijaya (2012:164) dalam (Siti Salbiyah, 2018), pengertian dari empat kelompok variabel-variabel bauran promosi, sebagai berikut:

1. Advertising, yaitu bentuk presentasi dan promosi bukan pribadi tentang ide, produk dan jasa yang dibayar oleh sponsor tertentu. Dalam pemasaran jasa pendidikan, "Periklanan yaitu bentuk-bentuk komunikasi yang meliputi siaran radio (broadcast), 
materi tercetak (print), internet, papan reklame (Outdoor Advertising) dan surat langsung (directmail) yang dilakukan pemasar jasa pendidikan” (Wijaya 2012:165) dalam (Siti Salbiyah, 2018).

2. Personal Selling yaitu penyampaian secara lisan mengenai produk dalam bentuk percakapan dengan satu atau lebih calon pembeli yang diarahkan untuk menciptakan penjualan. Dalam pemasaran jasa pendidikan, penjualan pribadi bisa disebut dengan komunikasi pribadi, dalam artian "komunikasi yang secara langsung antara pemasar jasa pendidikan dan konsumen jasa pendidikan yang melibatkan percakapan dua arah dalam menyapaikan penjualan produk jasa pendidikan, seperti percakapan tatap muka, panggilan telepon dan surat elektronik" (Wijaya 2012:164) dalam (Siti Salbiyah, 2018).

3. Publicity, yaitu upaya yang dilakukan perusahaan untuk menciptakan permintaan bukan secara pribadi pada produk, jasa, atau ide dengan menggunakan berita komersial di media massa dan sponsor yang tidak dibebankan sejumlah pembayaran secara langsung. Adapun dalam jasa pendidikan untuk memicu minat yang efektif terhadap sekolah dan produk jasa pendidikan lainya dapat melalui penyebaran berita baru, membuat konverensi pers, menyelenggarakan peristiwa istimewa dan mendanai (memberikan modal) kegiatan yang pantas dijadikan sebuah berita oleh pihak ketiga sekolah" (Wijaya 2012:165) dalam (Siti Salbiyah, 2018).

4. Sales Promotion, yaitu kegiatan penjualan selain penjualan pribadi, periklanan dan publisitas yang memberikan dukungan terhadap pembelian konsumen dan efektivitas peritel dalam bentuk peragaan, pertunjukan, pameran, demonstrasi dan sebagainya. Dalam pemasaran jasa pendidikan "Promosi penjualan yaitu bentuk motivasi jangka pendek yang ditawarkan kepada pelanggan jasa pendidikan maupun perantara jasa pendidikan untuk memicu pembelian produk jasa pendidikan, sales promotion dalam jasa pendidikan dapat berupa kupon (coupon) produk jasa pendidikan, diskon (discout) produk jasa pendidikan, hadiah (gift) dan promosi berhadiah (prize promotion)" (Wijaya 2012: 165) dalam (Siti Salbiyah, 2018).

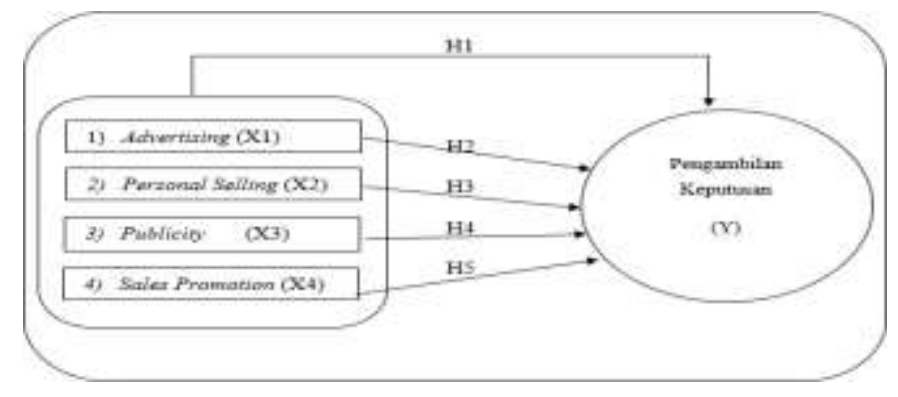

Gambar 1. Kerangka Penelitian

3. METODE PENELITIAN

\subsection{Lokasi Penelitian}

Penelitian ini dilakukan pada Universitas Sarjanawiyata Tamansiswa Yogyakarta.

\subsection{Populasi dan Sampel}


Populasi dalam penelitian ini adalah mahasiswa Universitas Sarjanawiyata Tamansiswa angkatan 2019/2020 sebanyak 2.457 orang, angkatan 2020/2021 sebanyak 1.813 orang.

Teknik pengambilan sampel penelitian ini menggunakan rumus Slovin. Sehingga sampel penelitian ini sebanyak 135 responden.

\subsection{Teknik Pengumpulan Data}

Metode pengumpulan data yang digunakan dalam penelitian ini adalah metode angket (kuesioner terstruktur) yang diberikan kepada responden. Metode angket menurut (Imasari \& Lu, 2010) merupakan teknik pengumpulan data yang dilakukan dengan cara memberi seperangkat pertanyaan tertulis kepada responden untuk dijawabnya, dimana peneliti tidak langsung bertanya jawab dengan responden pernyataan tertulis kepada responden untuk menjawabnya.

\subsection{Teknik Analisis Data}

Dalam penelitian ini, teknik analisis regresi linier berganda digunakan. Analisis regresi linier berganda merupakan analisis yang digunakan oleh peneliti, bila bermaksud meramalkan pengaruh setiap variabel bebas secara bersama-sama terhadap variabel terikat. Analisis ini digunakan untuk mengetahui besarnya pengaruh dua atau lebih variabel bebas dengan cara bersama terhadap satu variabel terikat, dan analisis regresi linier secara umum digunakan untuk menguji hipotesis.(Sandy, 2014). Analisis linear berganda pada penelitian ini digunakan untuk mengetahui pengaruh Advertising (X1), Personal Selling (X2), Publicity (X3), dan Sales Promotion (X4) terhadap Keputusan Mahasiswa (Y). Pada penelitian ini untuk menjawab hipotesis peneliti menggunakan regresi linier berganda dengan pengolahan datamenggunakan software SPSS (Statistical Package For Social Science) dengan formulasi sebagai berikut:

$$
\mathrm{Y}=\mathrm{a}+\mathrm{b} 1 \mathrm{X} 1+\mathrm{b} 2 \mathrm{X} 2+\mathrm{b} 3 \mathrm{X} 3+\mathrm{b} 4 \mathrm{X} 4+\mathrm{e}
$$

Dimana :

$\mathrm{Y}=$ Keputusan Mahasiswa Baru

$\mathrm{X} 1=$ Advertising

$\mathrm{X} 2 \quad=$ Personal Selling

$\mathrm{X} 3=$ Publicity

$\mathrm{X} 4=$ Sales Promotion

b1,b2,b3,b4 = Koefisien regresi, i = 1,2,3,4

e = Variabel yang belum terungkap, epsilon

Sumber : (Sandy, 2014) yang kemudian dikembangkan oleh peneliti untuk penelitian ini.

Dimana :

$$
\mathrm{KMB}=\mathrm{a}+\mathrm{b} 1 \mathrm{Adv}+\mathrm{b} 2 \mathrm{Ps}+\mathrm{b} 3 \mathrm{Pc}+\mathrm{b} 4 \mathrm{Sp}+\mathrm{e}
$$


$\mathrm{KMB}=$ Keputusan Mahasiswa

Baru Adv = Advertising

Ps = Personal Selling

Pc $\quad=$ Publicity

$\mathrm{Sp} \quad=$ Sales Promotion

b1,b2,b3,b4 = Koefisien regresi, i = 1,2,3,4

e = Variabel yang belum terungkap, epsilon

\section{Hasil dan Pembahasan Karakteristik Responden}

Hasil dari pengujian data pada penelitian ini, diolah menggunakan Software SPSS ver.

23.0. dengan tahapan uji kualitas data, uji regresi linier berganda, dan uji hipotesis.

\section{1 karakteristik responden}

Karakteristik data responden- responden yang terdapat pada penelitian ini meliputi jenis kelamian, asal daerah, mahasiswa fakultas, dan tahun angkatan. Deskripsi karakteristik responden disajikan pada tabel 1 berikut: Keseluruhan jumlah angkatan 2019/202- \& 2020/2021 menjadi populasi pada penelitian ini yang berjumlah 4,270 mahasiswa. Dalam menentukan sampel yang akan digunakan peneliti menggunakan rumus Slovin (Ratno, 2017), yang kemudian di hasilkan 135 sampel yang digunakan pada penelitian. Selanjutnya untuk karakteristik responden dapat dilihat pada tabel 1 :

\section{Tabel 1}

\section{karakteristik}

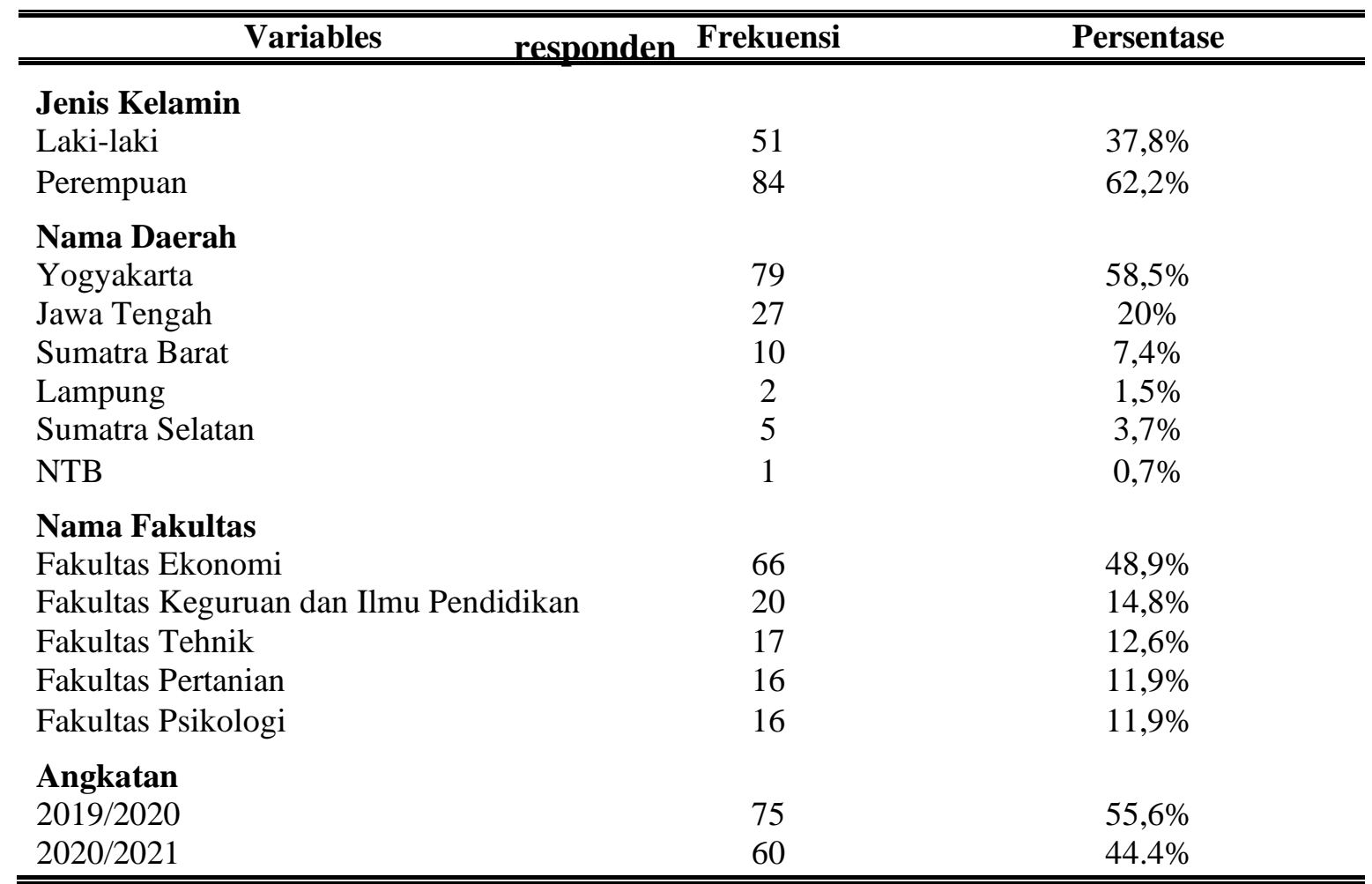


Note $: \mathbf{n}=\mathbf{1 3 5}$

\section{Sumber : Hasil Olah Data 2020}

Berdasarkan tabel 1 menunjukkan bahwa mayoritas yang menjadi responden pada penelitian adalah perempuan dengan presentase $62,2 \%$, untuk asal daerah mayoritas responden berasal dari daerah Yogyakarta dengan persentase 58,5\%, kemudian untuk fakultas mayoritas responden yang mengisi dari fakultas ekonomi dengan persentase 48,9\%, dan terakhir untuk tahun angkatan mayoritas responden yang mengisi dari angkatan 2019/2020.

\subsection{Uji Asumsi}

Kelasik Uji

\section{Normalitas}

Alasan peneliti menggunakan uji normalitas dalam penelitian ini adalah untuk mengetahui apakah dalam model regresi, variable residual berdistribusi normal atau tidak. Hasil uji normalitas pada penelitian ini dapat dilihat pada tabel gambar berikut :

\section{Gambar 2}

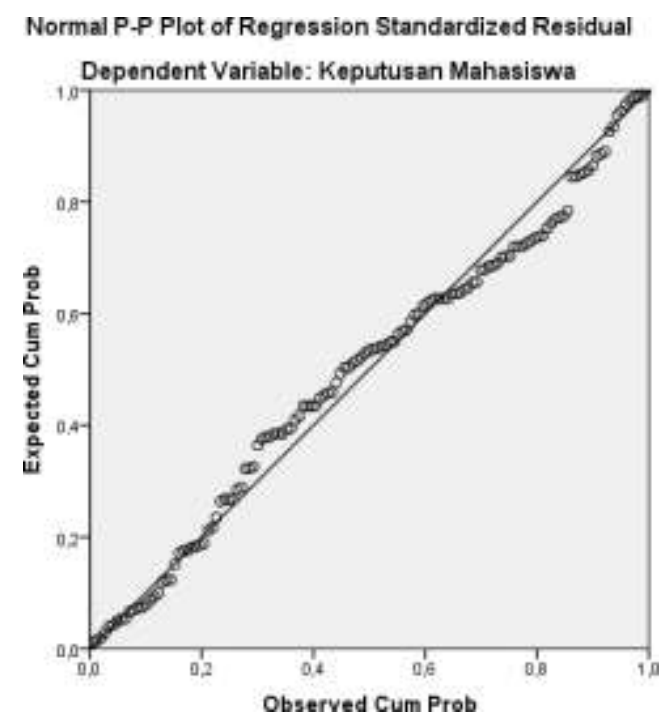

Sumber : Hasil Olah Data 2020

Dari gambar 4.1 dapat terlihat bahwa titik-titik menyebar disekitas garis diagonal dan mengikuti arah garis diagonal maka dapat ditarik kesimpulan bahwa model regresi memenuhi asumsi uji normalitas yang berarti data pada penelitian ini telah terdistribusi dengan normal. Uji Multikolinearitas

Uji multikolinearitas ini digunakan untuk mengatahui ada atau tidaknya hubungan linear antar variabel independent dalam model regresi. Uji multikolinearitas dapat dilakukan dengan melihat nilai Varian Inflation Factor (VIF), jika hasil pada uji multikolinearitas 
menunjukkan nilai varian (VIF) < 10 dan nilai Toleance $>0,01$ maka dapat disimpulkan bahwa tidak terjadi multikolinearitas. Hasil uji multikolinearitas pada penelitian ini dapat dilihat pada table 4.18 berikut :

Tabel 3

Coefficients $^{\mathrm{a}}$

\begin{tabular}{|c|c|c|c|c|c|c|c|c|}
\hline & \multirow[b]{2}{*}{ Model } & \multicolumn{2}{|c|}{$\begin{array}{l}\text { Unstandardized } \\
\text { Coefficients }\end{array}$} & \multicolumn{2}{|l|}{$\begin{array}{c}\text { Standardized } \\
\text { Coefficients }\end{array}$} & \multirow[b]{2}{*}{ Sig. } & \multicolumn{2}{|c|}{$\begin{array}{l}\text { Collinearity } \\
\text { Statistics }\end{array}$} \\
\hline & & B & $\begin{array}{l}\text { Sta. } \\
\text { Error }\end{array}$ & Beta & $\mathbf{t}$ & & Tolerance & VIF \\
\hline \multirow[t]{5}{*}{1} & (Constant) & 3,379 & ,926 & & 3,649 & 000 & & \\
\hline & Advertising & ,381 & ,059 & ,403 & 6,483 & ,000 & ,729 & 1,371 \\
\hline & $\begin{array}{l}\text { Personal } \\
\text { Selling }\end{array}$ & ,084 & ,050 &, 114 & 1,693 & ,093 & ,621 & 1,610 \\
\hline & Publicity & ,096 & ,055 & ,138 & 1,733 & ,086 & , 442 & 2,264 \\
\hline & $\begin{array}{l}\text { Sales } \\
\text { Promotion }\end{array}$ & 244 & ,057 & ,332 & 4,291 & ,000 & ,469 & 2,132 \\
\hline
\end{tabular}

a. Dependent Variable: Keputusan Mahasiswa

Sumber : Hasil Olah Data 2020

Berdasarkan tabel 4.18 diketahui bahwa nilai variance inflaction factor (VIF) dari 4 variabel antara lain Advertising menunjukkan nilai VIF 1,371 $<10$ dan nilai tolerance 0,729 $>0,1$, Persolan Selling menunjukkan nilia VIF 1,610 < 10 dan nilai tolerance 0,621 > 0,1, Publicity menunjukan nilai VIF 2,264 < 10 dan nilai tolerance 0,442 > 0,1, Sales Promotion menunjukkan nilai VIF 2,132 < 10 dan nilai tolerance $0,469>0,1$. Dari semua hasil uji Multikoliniearitas yang telah dilakukan dapat ditarik kesimpulan bahwa dimasing-masing variabel independen tidak terjadi Multikoliniearitas.

\section{Uji Heterokedastisitas}

Uji Heterokedastisitas ini dilakukan untuk menguji apakah dalam penelitian ini terjadi ketidaksamaan varian dari residual satu pengamatan pada model regresi. Suatu model regresi yang baik adalah tidak terjadinya Heterokedastisitas. Ada atau tidakya heterokedastisitas dalam model regresi dapat dilihat dari Scatterplot, jika titik-titik membentuk suatu pola tertentu yang teratur maka dalam model regresi tersebut telah terjadi heterokedastisitas. Sebalinya jika titik- titik membentuk pola yang tidak jelas maka model regresi tersebut tidak terjadi heterokedastisitas. Hasil uji heterokedastisitas pada penelitian ini dapat dilihat sebagai berikut 


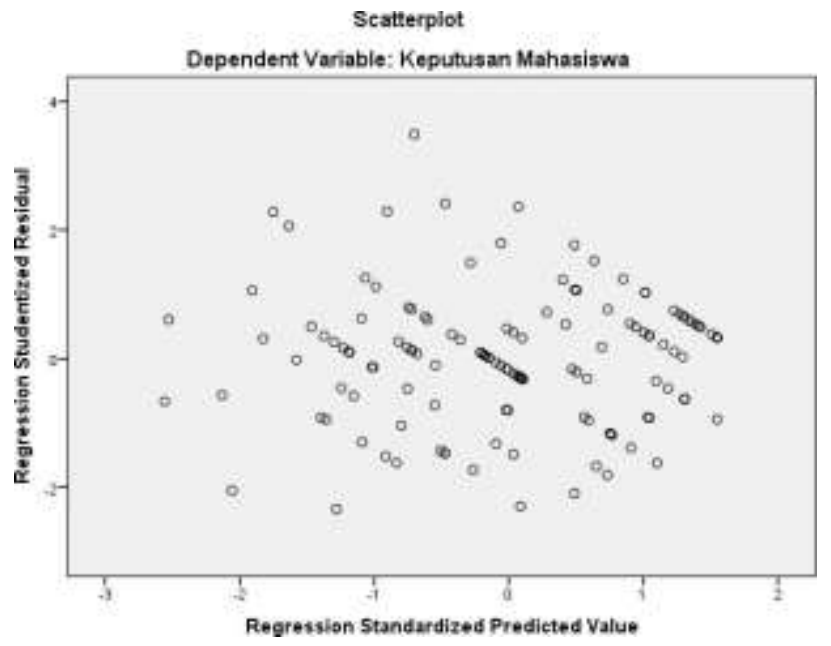

Sumber : Hasil Olah Data 2020

Dari grafik 4.2 terlihat bahwa tidak adannya pola yang jelas dan terlihat jelas bahwa titik-titik menyebar secara acak diatas dan dibawah angkat nol (0) pada sumbu Y. Sehingga dapat disimpukan tidak terjadi Heterokedastisitas.

\section{Uji Regresi Berganda}

Uji regresi linier berganda ini dilakukan untuk melihat sejauh mana pengaruh variabel independen (Advertising, Personal Selling, Publicity, dan Sales Promotion) dan variabel dependen ( Keputusan Mahasiswa Baru).

\section{Tabel 4}

\section{Coefficients $^{\mathrm{a}}$}

\begin{tabular}{|c|c|c|c|c|c|c|}
\hline & \multirow[b]{2}{*}{ Model } & \multicolumn{2}{|c|}{$\begin{array}{l}\text { Unstandardized } \\
\text { Coefficients }\end{array}$} & \multirow{2}{*}{$\begin{array}{c}\text { Standardized } \\
\text { Coefficients }\end{array}$} & \multirow[b]{2}{*}{ t } & \multirow[b]{2}{*}{ Sig. } \\
\hline & & B & Std. Error & & & \\
\hline \multirow[t]{5}{*}{1} & (Constant) & 3,379 & ,926 & & 3,649 &, 000 \\
\hline & Advertising & ,381 & 059 & ,403 & 6,483 & 000 \\
\hline & Personal Selling & ,084 &, 050 & , 114 & 1,693 & ,093 \\
\hline & Publicity & 096 & 055 &, 138 & 1,733 & ,086 \\
\hline & Sales Promotion & 244 & 057 & ,332 & 4,291 & 000 \\
\hline
\end{tabular}

a. Dependent Variable: Keputusan Mahasiswa Baru

Sumber : Hasil Olah Data 2020

$$
\text { KMB }(Y)=\text { 3,379 + 0,381 Adv }(X 1)+0,084 \text { Ps }(X 2)+0,096 \text { Pc(X3) + 0,244 Sp(X4) }
$$

Berdasarkan hasil uji persamaan regresi pada tabel 4.19 dapat dilihat angka konstanta 3,379 berarti keputusan mahasiswa baru akan konstan sebesar 3,379 yang dipengaruhi oleh Advertising (Adv), Personal Selling (Ps), Publicity(Pc), dan Sales Promotion (Sp). Kemudian nilai 0,381 Adv berarti setiap panambahan atau pengurangan 1 (satu) skor Advertising akan mempengaruhi keputusan mahasiswa baru sebanyak 0,381 point, nilai 0,084 Ps berarti setiap penambahan atau pengurangan 1 (satu) skor Personal Selling akan mempengaruhi keputusan mahasiswa baru sebanyak 0,084 point. Nilai 0,096 Pc berarti setiap penambahan atau 
pengurangan 1 (satu) skor Publicity akan mempengaruhi keputusan mahasiswa baru sebanyak 0,096 point. Dan nilai 0,244 Sp berarti setiap penambahan atau pengurangan 1 (satu) skor Sales Promotion akan mempengaruhi keputusan mahasiswa baru sebanyak 0,244 point.

\section{Uji Hipotesis}

Uji hipotesis ini meliputi 2 uji yaitu Uji F dan Uji t. Uji F merupakan Kriterian pengujian hipotesis untuk uji serempak (Uji F) untuk melihat signifikan secara simultan variabel terikat (dependent) terhadap variabel bebas (independent). Dengan ketentuan jika nilai Fhitung > Ftabel $(3,070)$, maka Ho ditolak dan Ha diterima sebaliknya apabila nilai Fhitung $\leq$ Ftable $(3,070)$, maka Ho diterima dan Ha ditolak. Sedangkan Uji t merupakan uji untuk melihat pengaruh secara parsila masing-masing variabel bebas (independent) terhadap variabel terikat (dependent). Dengan ketentuan apabila hasil thitung $>$ ttable $(1,6562)$ atau thitung $<$ ttable $(1,6562)$ maka Ho ditolak dan Ha diterima, sebaliknya jika thitung $\leq$ ttable atau thitung $\geq$ table maka Ho diterima dengan Ha ditolak.

\section{Tabel 5}

\begin{tabular}{llrrrrr}
\multicolumn{8}{c}{ ANOVA $^{\mathbf{a}}$} \\
\hline & Model & Sum of Squares & df & Mean Square & F & \multicolumn{1}{c}{ Sig. } \\
\hline 1 & Regression & 572,000 & 4 & 143,000 & 56,379 &, $000^{\text {b }}$ \\
& Residual & 329,734 & 130 & 2,536 & & \\
Total & 901,733 & 134 & & & \\
\hline
\end{tabular}

a. Dependent Variable: Keputusan Mahasiswa Baru

b. Predictors: (Constant), Sales Promotion, Personal Selling, Advertising, Publicity

Sumber : Hasil Olah Data 2020

Berdasarkan tabel 5 yang memperlihatkan hasil pengujian secara simultan mendapatkan kesimpulan bahwa besarnya F-hitung adalah 56,379 dan nilai sig sebesar 0,000. Jadi ini membuktikan bahwa nilai F-hitung 56,379 > 3,070 dan nilai sig 0,000<0,05. Maka hasil dari penelitian ini Ha diterima dan Ho ditolak. Sehingga dari hasil pengujian ini dapat disimpulkan bahwa variabel independen (Advertising, Personal Selling, Publicity, dan Sales Promotion) berpengaruh secara simultan terhadap variabel dependen (Keputusan Mahasiswa).

\section{Tebel 6}

\section{Coefficients $^{\mathrm{a}}$}

\begin{tabular}{|c|c|c|c|c|c|c|}
\hline & \multirow[b]{2}{*}{ Model } & \multicolumn{2}{|c|}{$\begin{array}{l}\text { Unstandardized } \\
\text { Coefficients }\end{array}$} & \multirow{2}{*}{$\begin{array}{c}\text { Standardized } \\
\text { Coefficients } \\
\text { Beta }\end{array}$} & \multirow[b]{2}{*}{$\mathbf{t}$} & \multirow[b]{2}{*}{ Sig. } \\
\hline & & B & Std. Error & & & \\
\hline \multirow[t]{5}{*}{1} & (Constant) & 3,379 & ,926 & & 3,649 &, 000 \\
\hline & Advertising & ,381 & 059 & $40 z$ & 6,483 &, $00 c$ \\
\hline & Personal Selling & ,084 &, 050 &, 114 & 1,693 & ,09: \\
\hline & Publicity & ,096 & 055 & , & 1,733 & , 086 \\
\hline & Sales Promotion & ,244 & 057 & ,332 & 4,291 &, 000 \\
\hline
\end{tabular}

a. Dependent Variable: Keputusan Mahasiswa Baru

Sumber : Hasil Olah Data 2020 
Berdasarkan tabel 5 menunjukkan bahwa hasil dari uji parsial menyatakan bahwa nilai t-hitung sebesar 6,483 dan nilai sig 0.000. Hasil ini menunjukkan bahwa nilai sig $0.000<0.05$. Maka Ha diterima dan Ho ditolak. Sehingga Hasil uji hipotesis ini dapat disimpulkan bahwa Advertising berpengaruh terhadap Keputusan Mahasiswa; hasil dari uji parsial menyatakan bahwa nilai t-hitung sebesar 1,693 dan nilai sig 0.086. Hasil ini menunjukkan bahwa nilai sig $0.093>0.05$. Maka Ha ditolak dan Ho diterima. Sehingga Hasil uji hipotesis ini dapat disimpulkan bahwa Personal Selling tidak berpengaruh terhadap Keputusan Mahasiswa; hasil dari uji parsial menyatakan bahwa nilai t-hitung sebesar 1,733 dan nilai sig 0.086 . Hasil ini menunjukkan bahwa nilai sig $0.086<0.05$. Maka Ha ditolak dan Ho diterima. Sehingga Hasil uji hipotesis ini dapat disimpulkan bahwa Publicity tidak berpengaruh terhadap Keputusan Mahasiswa; hasil dari uji parsial menyatakan bahwa nilai t-hitung sebesar 4,291 dan nilai sig Hasil ini menunjukkan bahwa nilai sig $0.000<0.05$. Maka Ha diterima dan Ho ditolak. Sehingga Hasil uji hipotesis ini dapat disimpulkan bahwa Sales Promotion berpengaruh terhadap Keputusan Mahasiswan.

\section{Uji Koefisien Determinasi $\left(R^{2}\right)$}

Uji koefisien determinasi $\left(R^{2}\right)$ dilakukan dalam penelitian ini dengan tujuan mengetahui seberapa besar kemampuan model dalam menjelaskan variasi dependen. Hasil uji koefisiens determinasi dapat dilihat pada tabel 4.20 sebagai berikut :

Tabel 7

\begin{tabular}{|c|c|c|c|}
\hline \multicolumn{4}{|c|}{ Model } \\
\hline Model & $\mathbf{R}$ & $\begin{array}{c}\text { Adjusted R } \\
\text { R Squafymmasy }\end{array}$ & $\begin{array}{l}\text { Std. Error of the } \\
\text { Estimate }\end{array}$ \\
\hline 1 &, $796^{\mathrm{a}}$ & ,634 & 1,593 \\
\hline
\end{tabular}

a. Predictors: (Constant), Sales Promotion, Personal Selling, Advertising, Publicity

b. Dependent Variable: Keputusan Mahasiswa

Sumber : Hasil Olah Data 2020

Berdasarkan tabel 4.22 hasil pengujian koefisien determinasi menunjukan nilai Adjusted $R$ Square sebesar 0,623 yang berarti besarnya kontribusi variabel independen independen (Advertising, Personal Selling, Publicity, dan Sales Promotion) tehadap pengaruh variabel dependen (Keputusan Mahasiswa) sebesar 62\%, sedangkan sisanya 38\% ini dipengaruhi oleh fakto-faktor pada variabel dependen lain yang tidak diteliti pada penelitian ini.

\section{Standardized Beta Coefficients}

Hasil Standarized Beta Coeficient dapat dilihat pada tabel 4.15 berikut.

Tabel 8

\begin{tabular}{lcc}
\hline \multicolumn{1}{c}{$\begin{array}{c}\text { Variabel } \\
\text { Independen }\end{array}$} & $\begin{array}{c}\text { Variabel } \\
\text { Dependen }\end{array}$ & $\begin{array}{c}\text { Standarized Beta } \\
\text { Coeficient }\end{array}$ \\
\hline \hline Advertising & Keputusan & 0,403 \\
Personal Selling & Mahasiswa & 0,114 \\
Publicity & & 0,138
\end{tabular}




Sales Promotion 0,332

Sumber: Hasil Olah Data 2020

Berdasarkan tabel 4.23 diatas variabel paling dominan dalam penelitian ini dan paling berpengaruh terhadap Keputusan Mahasiswa adalah Advertising dengan nilai sebesar 0,403 diikuti dengan variabel Sales Promotion dengan nilai 0,332. variabel Publicity dengan nilai 0,138 dan variabel Personal Selling dengan nilai 0,114.

\section{Kesimpulan}

Berdasarkan hasil dan pembahasan di atas, dengan tujuan penelitian untuk menganalisis pengaruh bauran promosi yang paling berpengaruh terhadap Keputusan Mahasiswa dalam memilih Universitas Sarjanawiyata Tamansiswa akan dijelaskan sebagai berikut :.

1. Berdasarkan hasil dari analisi regresi linier berganda, secara simultan variabel bauran promosi yang terdiri atas Advertising, Personal Selling, Publicity, dan Sales Promotion, berpengaruh signifikan terhadap Keputusan Mahasiswa dalam memilih Universitas Sarjanawiyata Tamansiswa.

2. Berdasarkan hasil dari analisi regresi linier berganda, secara parsial variabel Advertising berpengaruh signifikan terhadap Keputusan Mahasiswa dalam memilih Universitas Sarjanawiyata Tamansiswa.

3. Berdasarkan hasil dari analisi regresi linier berganda, secara parsial variabel Personal Selling tidak berpengaruh signifikan terhadap Keputusan Mahasiswa dalam memilih Universitas Sarjanawiyata Tamansiswa.

4. Berdasarkan hasil dari analisi regresi linier berganda, secara parsial variabel Publicity tidak berpengaruh segnifikan terhadap Keputusan Mahasiswa dalam memilih Universitas Sarjanawiyata Tamansiswa.

5. Berdasarkan hasil dari analisi regresi linier berganda, secara parsial variabel Sales Promotion berpengaruh signifikan terhadap Keputusan Mahasiswa dalam memilih Universitas Sarjanawiyata Tamansiswa.

\section{Keterbatasan Dan Saran}

Bagi Pengelola Bagian Pemasaran Universitas Sarjanawiyata Tamansiswa. Berdasarkan penelitian yang telah dilakukan oleh peneliti diketahui bahwa variabel Advertising dan Sales Promotion berpengaruh terhadap Keputusan Mahasiswa dalam memilih Universitas Sarjanawiyata Tamansiswa. Oleh karena itu pengelola bagian Promotion Universitas Sarjanawiyata Tamansiswa, diharapkan dapat mempertahankan variabel Advertising dan Sales Promotion, serta kalau bisa dijadikan sebagai fokus utama dalam Promotion Universitas Sarjanawiyata Tamansiswa. Yang nantinya dapat digunakan sebagai alat dalam menghadapi persaingan Universitas lain, bahkan dapat digunakan sebagai alat utama dalam meningkatkan jumlah mahasiswa. Sedangkan hasil yang berbeda didapatkan pada variabel Personal Selling dan Publicity, yang mana pada penelitian ini didapatkan hasil bahwa variabel Personal Selling dan Publicity kurang mampu mempengaruh Keputusan Mahasiswa dalam memilih Universitas Sarjanawiyata Tamansiswa. Sehingga variabel Personal Selling dan Publicity harus lebih ditingkatkan agar variabel tersebut 
mampu mempengaruhi Keputusan Mahasiswa dalam memilih Universitas Sarjanawiyata Tamansiswa.

Bagi peneliti selanjutnya yang tertarik dengan tema yang sama, bisa dikembangkan dalam penelitian dengan menambah atau mengurangi jumlah data yang diteliti dan menambahkan pertanyaan disetiap indikatornya sehingga hasil yang diperoleh lebih akurat dan mempunyai cakupan yang lebih luas.

\section{Daftra pustaka}

Abdi, M., \& Hariyadi. (2017). Pengaruh Bauran Promosi Terhadap Keputusan Mahasiswa Memilih Universitas Muhammadiyah Sumatera Barat. Menara Ilmu, XI(77), 155-161.

Astuti, S. (2015). Analisis Bauran Promosi Dalam Peningkatan Jumlah Mahasiswa Baru di FKIP UHAMKA Jakarta. Jurnal Utilitas, 1,1 .

Imasari, K., \& Lu, C. (2010). Pengaruh Media Periklanan Terhadap Pengambilan Keputusan Siswa SMU Untuk Mendaftar di Universitas Kristen Maranatha: Sikap Konsumen Sebagai Variabel Moderasi (Studi Kasus Siswa SMU di Bandung) Kartika Imasari. Jurnal Bisnis Dan Ekonomi, 17(2), 109-120.

Jasmani, J., \& Sunarsi, D. (2020). The Influence of Product Mix, Promotion Mix and Brand Image on Consumer Purchasing Decisions of Sari Roti Products in South Tangerang. PINISI Discretion Review, 1(1), 165. https://doi.org/10.26858/pdr.v1i1.13409

Mulyawan, A., \& Komarudin. (2012). Pelaksanaan Aspek Bauran Promosi Pada Stmik Mardira Indonesia, Bandung. Jurnal Computech \& Bisnis, 6(1), 47-59. Retrieved from http://jurnal.stmik-mi.ac.id/index.php/jcb/article/view/86

Novita Klarisa. (2013). Pengaruh Bauran Promosi Terhadap Keputusan Pembelian Konsumen Di Swalayan Maxi Balikpapan. Jurnal Manajemen, 1-15.

Ratno, F. A. (2017). Pengaruh Promotional Mix Terhadap Keputusan Mahasiswa Memilih Universitas Sebelas Maret Surakarta. Jurnal Ekonomi Manajemen \& Bisnis, 18(2), 177190.

Sandy, F. (2014). PENGARUH BAURAN PROMOSI TERHADAP KEPUTUSAN PEMBELIAN (Survei pada Mahasiswa Jurusan Bisnis Angkatan 2010-2012 Fakultas Ilmu Administrasi Pengguna Indosat di Universitas Brawijaya). Jurnal Administrasi Bisnis S1 Universitas Brawijaya, 9(2), 1-10.

Setiono, B. A. (2010). ANALISIS PENGARUH BAURAN PROMOSI TERHADAP KEPUTUSAN MENJADI TARUNA / TARUNI PROGRAM DIPLOMA PELAYARAN UNIVERSITAS HANG TUAH SURABAYA Benny Agus Setiono Jurusan Ketatalaksanaan Pelayaran Niaga , Program Diploma Pelayaran, Universitas Hang Tuah PENDAHULUAN. 2, 103-121.

Setyowati, E. S., \& Aesthetika, N. M. (2018). Pengaruh Bauran Promosi terhadap Pengambilan Keputusan Memilih Universitas Muhammadiyah Sidoarjo (UMSIDA) 
(Studi pada Mahasiswa Alumni SMA Kemala Bhayangkari 3 Porong). KANAL: Jurnal Ilmu Komunikasi, 5(2), 131. https://doi.org/10.21070/kanal.v5i2.1481

Siti Salbiyah, B. W. M. (2018). PENGARUH BAURAN PROMOSI TERHADAP MINAT MEMILIH PRODI MANAJEMEN FAKULTAS EKONOMI DAN BISNIS UMSURABAYA TAHUN 2017. XV(September), 160-164.

Sulaiman. (2012). Skripsi Pengaruh Bauran Promosi ( Promotional Mix ) Terhadap Peningkatan Penjualan Pada Universitas Islam Negeri. (Promotional Mix).

Sutrisno, E. (2019). Pengaruh Bauran Promosi Terhadap Keputusan Mahasiswa Kuliah Di Sekolah Tinggi Teknologi Kedirgantaraan (STTKD) Yogyakarta. 10(2017), 61-71.

Zainurin Dahari. (2011). Factors influencing international students' choice towards universities in Malaysia. African Journal of Business Management, 5(26), 1061510620. https://doi.org/10.5897/ajbm11.521 